\title{
Associations between decreased fertility and management factors, claw health, and somatic cell count in Swedish dairy cows
}

\author{
H. Lomander, ${ }^{* 1}$ C. Svensson,† C. Hallén-Sandgren,‡ H. Gustafsson, § and J. Frössling*\# \\ *Department of Animal Environment and Health, Swedish University of Agricultural Sciences, PO Box 234, SE-532 23 Skara, Sweden \\ †Växa Sverige Regional Dairy Association, PO Box 814, SE-391 28 Kalmar, Sweden \\ ‡DeLaval International AB, PO Box 39, SE-147 21 Tumba, Sweden \\ §Swedish Dairy Association and Department of Clinical Sciences, Swedish University of Agricultural Sciences, PO Box 7054, SE-750 07 Uppsala, \\ Sweden \\ \#Department of Disease Control and Epidemiology, National Veterinary Institute, SE-751 89 Uppsala, Sweden
}

\section{ABSTRACT}

The aim of this retrospective single-cohort study was to investigate if a rapid change in feeding, management, or housing or an increasing incidence of claw diseases or udder health problems is associated with decreased reproductive performance. Data on individual cows and herds were retrieved from the Swedish official milk recording system and questionnaire data on feeding system was obtained from the regional dairy associations. In total, 63,561 cows in 759 herds were included in the study. The associations between the probability of pregnancy at first insemination and number of inseminations per animal submitted for artificial insemination and potential predictor variables were investigated using a logistic regression model and a Poisson regression model, respectively. The results indicated that cows with severe claw lesions or an increasing somatic cell count after calving had a lower probability of pregnancy at first insemination and had a higher number of inseminations per animal submitted for artificial insemination than healthy cows. Variables representing a change in housing, production system, or milking system within the period from 6 mo before calving until establishment of a new pregnancy were significantly associated with decreased reproductive performance. No differences in fertility were observed between cows milked in an automatic milking system compared with cows milked conventionally. The results indicate that a change of system, rather than the actual type of milking or housing system negatively affects reproductive performance. Special attention should therefore be paid to the fertility of cows when the herd management is changing. It is also important to prevent claw lesions and increasing cell counts after calving to avoid a decrease in reproductive performance.

Received December 13, 2012.

Accepted June 16, 2013.

${ }^{1}$ Corresponding author: Hanna.Lomander@slu.se
Key words: total mixed ration, automatic milking system, loose-housing system, risk factor

\section{INTRODUCTION}

In recent decades, studies have shown an ongoing negative trend in dairy cow fertility worldwide (Lucy, 2001), including Europe and Sweden (Rodriguez-Martinez et al., 2008). In parallel, rapid technical progress and structural changes are occurring in the dairy industry. Between 2005 and 2011, the number of Swedish dairy herds was reduced by approximately $40 \%$ and the average size of the remaining 5,260 herds increased from 46 to 65 cows (Swedish Board of Agriculture, 2012). At the same time, cows are increasingly being kept in loose-house systems, being given TMR or partial mixed rations (PMR), and being milked in automatic milking systems (AMS). In 2004, 80\% of the world's AMS were installed in northwest Europe (Koning and Rodenburg, 2004) and 755 AMS had been installed in Sweden by 2010 (Lakic, 2011).

Keeping larger herds of cows in loose-housing systems may increase the risk of several diseases, such as claw diseases or lameness (Bergsten and Herlin, 1996; Kujala et al., 2009) and the incidence of subclinical mastitis (Hovinen et al., 2009). In turn, both claw diseases and subclinical mastitis have been shown to be risk factors for decreased fertility (Hultgren et al., 2004; Lavon et al., 2011). The feeding of the cows and their energy balance may also influence their reproductive performance (e.g., see Friggens, 2003). Concerns have been raised that TMR feeding throughout the lactation may decrease fertility due to cows being overconditioned at calving (Spörndly, 2005). These concerns are partially supported by Danish findings that cows fed a highenergy-density TMR from $100 \mathrm{~d}$ before expected calving had a higher BCS after calving, and a more severe negative energy balance than cows fed a low-energydensity TMR (Nielsen et al., 2010). Finally, little is known about the effects of AMS on fertility (Jacobs 
and Siegford, 2012). The aim of this study was to investigate if the negative trend in reproductive performance of Swedish dairy cows can be linked to the new feeding, management, or housing systems, or to occurrence of claw diseases or udder health.

\section{MATERIALS AND METHODS}

\section{Study Design}

The study was designed as a retrospective singlecohort study and is here reported according to the strengthening the reporting of observational studies in epidemiology (STROBE) statement (von Elm et al., 2007). It used a data set retrieved from the Swedish official milk recording scheme (SOMRS; Olsson et al., 2001) that was merged with complementary data on feeding management collected from a questionnaire to feed advisors. We included herds with more than 60 calving cows per year and cows calving from March 1, 2010, to February 28, 2011. The cow was the unit of interest. Each cow was followed from 6 mo before her first calving, occurring within the defined time period until the next calving or until she left the herd nonpregnant. If none of these events had occurred earlier, the follow-up period ended at the day of data retrieval (May 1, 2012).

\section{Data Collection}

Data from SOMRS. We retrieved data from SOMRS on individual identity, breed, parity, and calving date for the cows calving within the period of interest. We also retrieved dates of inseminations, dates and results of gynecological examinations, records of claw health from claw-trimming events (Eriksson, 2006), and information on dates and reasons for a cow leaving the herd, as well as individual monthly test-day milk yield and SCC. Finally, herd-level data, including housing, type of milking, and production system [i.e., whether the herd was organic and certified according to KRAV (Uppsala, Sweden) standards; KRAV, 2013], as well as dates of potential changes in system, were retrieved.

The Questionnaire. A questionnaire was sent to the directors of the farm advisory services at the 7 regional dairy associations in Sweden who further distributed it to the local farm advisors of each region. The questionnaire collected data on type of feeding system and on type of feeding advice provided in the herds of interest. More specifically, the questionnaire investigated whether the cows were fed TMR (i.e., all roughages and concentrates mixed and fed ad libitum; individual concentrate doses $<1 \mathrm{~kg} / \mathrm{d}$ during milking not included), PMR (i.e., some of the roughages and concentrates mixed and fed ad libitum, but $>1 \mathrm{~kg}$ of concentrates per day fed individually and separately from roughage), or individual feeding [separate (SEP) feeding; i.e., all roughages and concentrates fed separately and concentrates fed to cows individually]. A question on whether the herds received monthly feed advice based on milk yield and BCS in all cows was also included.

\section{Data Management}

The Outcome Variables. Two measures of reproductive performance were edited from the SOMRS data and further evaluated as outcomes; the dichotomous variable pregnant (or not pregnant) to first AI (PAI) and the count variable number of inseminations per animal that was submitted for AI (NINS). An AI event was considered to lead to establishment of pregnancy if it was followed by calving within 270 to $290 \mathrm{~d}$. When information on a subsequent calving was missing, the AI was also considered successful if followed by a rectal palpation or ultrasound examination confirming the pregnancy. All cows, for which information on whether she was pregnant or not to first AI were available were included in the analyses of PAI $(\mathrm{n}=58,975)$. All cows that had a minimum of 1 AI recorded within 30 to 365 DIM were included in the analyses of NINS $(\mathrm{n}=$ 63,561).

The Predictor Variables. Breed, calving season, claw status, the interval from calving to first AI (CFI), individual kilograms of ECM at the first test day after calving, 2 measures of SCC, and parity were evaluated as potential cow-level predictors of the outcomes, and were all retrieved from the SOMRS data. Breed was included using the 3 categories Swedish Red, Swedish Holsteins, or other breed. Calving season indicated whether a cow calved in winter (December-February), spring (March-May), summer (June-August), or autumn (September-November). The CFI interval was categorized as early ( $<60$ DIM), medium (61-100 DIM), or late ( $>100$ DIM) according to the 25th and 75th percentiles of the distribution in the study population. Claw status was categorized as no or mild lesion, severe lesion, or no trimming record available in SOMRS. The category no or mild lesion was used if the cow had been trimmed but recorded as "claw status ok," or if dermatitis (both digital dermatitis and the harmless interdigital dermatitis), heel horn erosion, or mild sole hemorrhages were recorded. Severe lesion represented severe sole hemorrhage, sole ulcer, double sole, claw abscess, or white line disease. The categories were chosen based upon the most common reasons for lameness in Swedish dairy cows (C. Bergsten, Swedish University of Agricultural Sciences, Alnarp, Sweden, 
personal communication). A cow was considered as being affected by her claw status during a period starting 3 mo before the day of trimming and ending 1 mo after trimming (Figure 1). If such a period overlapped, the time period from 1 mo before calving to the day of pregnancy or day of the nonpregnant cow leaving the herd, information about the cow's claw status was considered available (Figure 2). Two different variables describing the SCC status of the cow were tested. High SCC was used to indicate if a cow had a monthly milk record with a SCC $>200,000$ cells $/ \mathrm{mL}$ at least once in the time period between calving and conception, or until leaving the herd nonpregnant. Increasing SCC was used to indicate if the SCC of a cow went from low $(<200,000$ cells $/ \mathrm{mL})$ to increased $(>200,000$ cells $/ \mathrm{mL}$ ) during the same time period. A record of increasing SCC had to be preceded by at least 1 record of low SCC (disregarding the dry period), or be the very first record in a firstparity cow to be considered an increase. In addition, 2 consecutive records of low SCC were required before a cow with a previous increase could have a new increase. Individual kilograms of ECM at the first test day after calving within 40 DIM was categorized as low $(<21 \mathrm{~kg}$ of ECM), medium (22-31 kg of ECM), or high ( $>32$ $\mathrm{kg}$ of ECM), which corresponded to the 25th and 75th percentiles of the distribution in the study population. Parity was divided into parity 1,2 , or $\geq 3$.

Feed advice, feeding system, herd level of production, herd size, housing, milking system, production type, and region were considered potential herd-level predictors of the outcomes. Feed advice indicated whether a farm received monthly feed advice including measurement of BCS. Feeding system was defined as a herd using TMR, PMR, SEP feeding, or unknown, as defined in previous sections of this paper. Herd level of production indicated the mean production per cow and day in the herd and the herd was categorized based on the 25th and 75 th percentiles of the distribution in the study population, which resulted in 3 groups: low $(<27 \mathrm{~kg}$ of ECM), medium (28-32 kg of ECM), and high ( $>32 \mathrm{~kg}$ of ECM). Herd size indicated the number of cows calv-

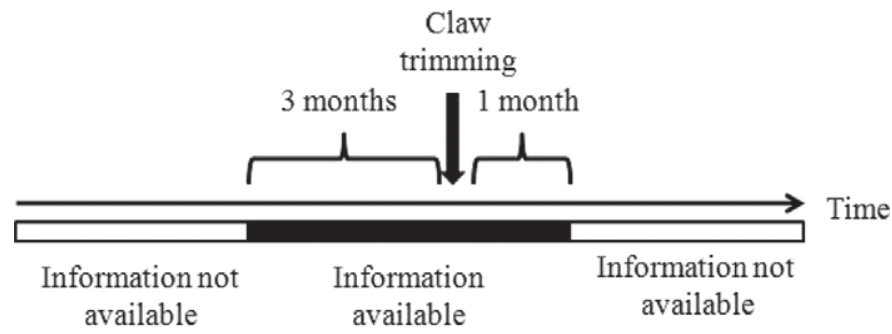

Figure 1. Time period for which information on a cow's claw status is considered available, in relation to the claw trimming and claw health recording. ing the year when the study was carried out and was treated as a continuous predictor. Housing was defined as a farm with tie-stalls, a loose-housing system, or a change from tie-stalls to a loose-housing system. The latter indicated a recorded change in type of housing during the period from 6 mo before a calving to the day a pregnancy was recorded or a nonpregnant cow left the herd (Figure 2). Milking system indicated whether the herd used AMS, conventional milking (i.e., in the tie-stall or in different types of parlors, including rotary parlors), or was changing from conventional to AMS. Comparable to housing, the category change was used when a change from conventional milking to AMS was recorded during the period from 6 mo before a calving to the day a pregnancy was recorded or a nonpregnant cow left the herd. Production system indicated whether the herd was organic and certified according to KRAV, nonorganic, or was changing from nonorganic to organic (change defined in the same way as for the variables milking and housing). Region corresponded to the 7 regional dairy advisory associations.

\section{Data Analysis}

The associations between the outcomes and potential predictor variables were evaluated using a logistic regression model for PAI and a Poisson regression model for NINS. Both models included a random intercept for herd to control for the clustering effect of cows within herds. The model-building strategy followed that proposed by Hosmer and Lemeshow (2000). Initially, the predictor variables were screened using univariate regression, where variables with $P<0.25$ were included in the general full model. The full models were reduced using stepwise backward elimination, and predictors with $P<0.05$ were kept in the models. Confounding was controlled for by examining the estimates of the remaining variable. If the removal of a predictor variable changed the estimate of a remaining predictor $>20 \%$,

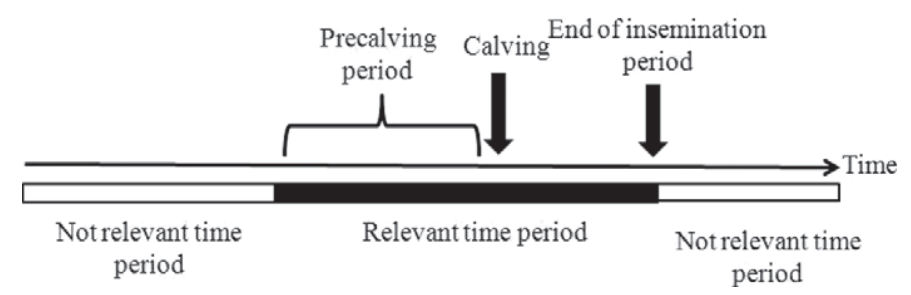

Figure 2. Time period of relevance in the categorization of the predictor variables claw status, housing, milking system, and production system. For claw status, the precalving period was set to $1 \mathrm{mo}$, and for the management system variables, to 6 mo. The definition applied in the study was that a cow experienced a change in system if the change occurred at any point within the relevant time period. 
the removed variable was considered as a confounder and kept in the model. Biologically relevant 2-way interactions involving the effects of main interest (i.e., feeding system, housing, and milking system) were then investigated. Model evaluation was made using models based on robust standard errors. The Poisson model was evaluated by examining predicted NINS compared with observed NINS. The influence of different covariate patterns on the probability of PAI in the logistic model was also evaluated. For the variables CFI, individual milk yield, and herd-level milk yield, both continuous and categorized forms were used and analysis of model fit showed that the continuous forms of these variables were better in the logistic models.

\section{RESULTS}

\section{Descriptive Data}

In January 2010, 4,023 Swedish dairy herds representing $85 \%$ of Swedish dairy cows were affiliated with SOMRS (Swedish Dairy Association, 2012) and the records included 1,734 herds that had more than 60 calving cows per year. Questionnaire data were obtained for 771 of the 1,734 herds included in the SOMRS data set.

Merging of the SOMRS and questionnaire data resulted in a data set with 91,162 cow observations from 771 herds. The number of participating herds and cows was reduced by removal of cows served by a bull $(\mathrm{n}=$ $3,842)$, cows subjected to embryo transfer $(\mathrm{n}=41)$, and cows lacking recorded data on insemination or other fertility data $(\mathrm{n}=19,738)$. Cows that received their first insemination within $30 \mathrm{~d}$ of calving $(\mathrm{n}=314)$ or more than $365 \mathrm{~d}$ after calving $(\mathrm{n}=85)$ were also excluded from the data set, as well as cows with missing observations on milk yield or lacking data on general herd-level production $(\mathrm{n}=3,510)$. The final data set hence included 63,561 cows in 759 herds.

The distribution of categorical predictor variables across cows and outcome variables is shown in Table 1. The continuous predictor herd size had a median of 119 cows (25th and 75th percentiles: 81 and 186).

\section{Probability of PAI}

The results from the logistic regression model of probability of PAI are compiled in Table 2. Cows that had claw records of severe lesions had lower probability of PAI [odds ratio $(\mathbf{O R})=0.83$ ] than cows with no lesions or mild lesions. On the other hand, cows with no recorded trimming had a higher probability of PAI $(\mathrm{OR}=2.24)$. Cows with increasing SCC after calving had a $60 \%$ lower probability of PAI $(\mathrm{OR}=0.40)$ than cows without an increase. Cows milked in an AMS did not have a lower probability of PAI than cows in a conventional system $(P=0.80)$. However, cows in herds that had a recorded change of milking system from conventional to AMS within the defined period had a significantly lower probability of PAI $(\mathrm{OR}=0.65)$ than cows in a herd with unchanged milking system. A significant interaction was found between feeding system and housing $(P=0.002)$. Cows that calved and were inseminated during a period of change from tie-stalls to loose housing and that were given TMR $(P=0.02)$ or PMR $(P<0.0001)$ had a 20 to $40 \%$ reduced probability of PAI, compared with cows not experiencing a change in housing and given SEP feeding. When the herd changed from nonorganic to organic, the probability of PAI in cows was reduced by $70 \%$, compared with nonorganic herds $(\mathrm{OR}=0.29)$.

The other significant variables in the final model were breed, calving season, CFI, individual kilograms of ECM, parity, and region. The covariates having high SCC, herd size, herd level of production, or whether the farm received advanced feed advice or not were, however, not significantly associated with the probability of PAI in the univariate screening, and were thus not included in the model.

\section{NINS}

Results from the Poisson regression model of NINS are summarized in Table 3. Cows with severe claw lesions received more inseminations [incidence risk ratio $(\mathbf{I R})=1.05]$ than cows with mild or no lesions. In addition, cows that displayed an increase in milk SCC after calving received more NINS (IR $=1.28)$ than cows without an increase. Cows milked in an AMS did not have significantly higher NINS than cows milked in a conventional system, but cows that were inseminated during a change to AMS had 10\% higher NINS (IR = 1.10) than cows in the conventional system. Also, a significant interaction between feeding system and housing was found $(P=0.0003)$. Cows held in a loose-housing system with PMR had significantly higher NINS compared with cows held in tie-stalls with SEP feeding (IR $=1.10)$. Cows having a change in housing and given TMR or PMR had significantly reduced incidence risk ratio of NINS (IR $=1.14$ and 1.12 , respectively) compared with cows kept in tie-stalls with SEP feeding and not experiencing a change in housing.

The other significant variables in the final model were breed, calving season, CFI, individual kilograms of ECM, parity, production system, and region. No significant association existed between NINS and herd size, the herd level of production, whether the farm received advanced feed counseling or not, or if the cow had a high SCC. 
Table 1. The distribution of predictor variables across cows and outcome variables in a study investigating risk factors for decreased fertility in Swedish dairy cows (2010-2011)

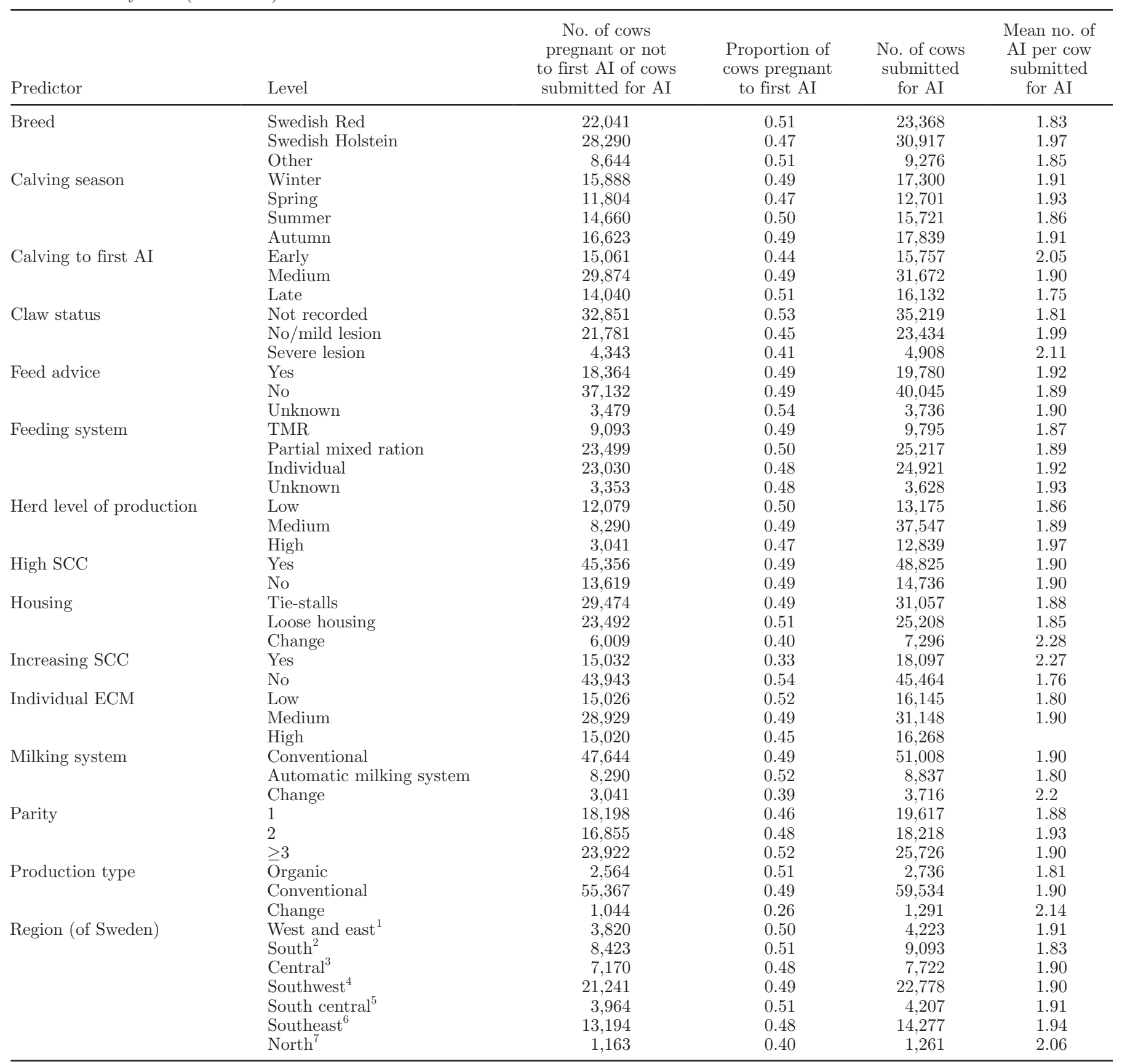

${ }^{1}$ Corresponding to the former regional dairy association of Freja Husdjur.

${ }^{2}$ Corresponding to the present regional dairy association of Skåne Semin.

${ }^{3}$ Corresponding to the former regional dairy association of Svea Husdjur.

${ }^{4}$ Corresponding to the former regional dairy association of Hallands Husdjur.

${ }^{5}$ Corresponding to the present regional dairy association of Södra Älvsborgs Husdjur.

${ }^{6}$ Corresponding to the former regional dairy association of Hansa Husdjur.

${ }^{7}$ Corresponding to the former regional dairy association of Norrmejeriers producenttjänst. 
Table 2. Results [shown as odds ratios $(\mathrm{OR})$ and $95 \% \mathrm{CI}$ ] of a logistic regression model used to investigate the effect of risk factors on the probability of pregnancy to first AI in 58,975 dairy cows in 759 Swedish herds

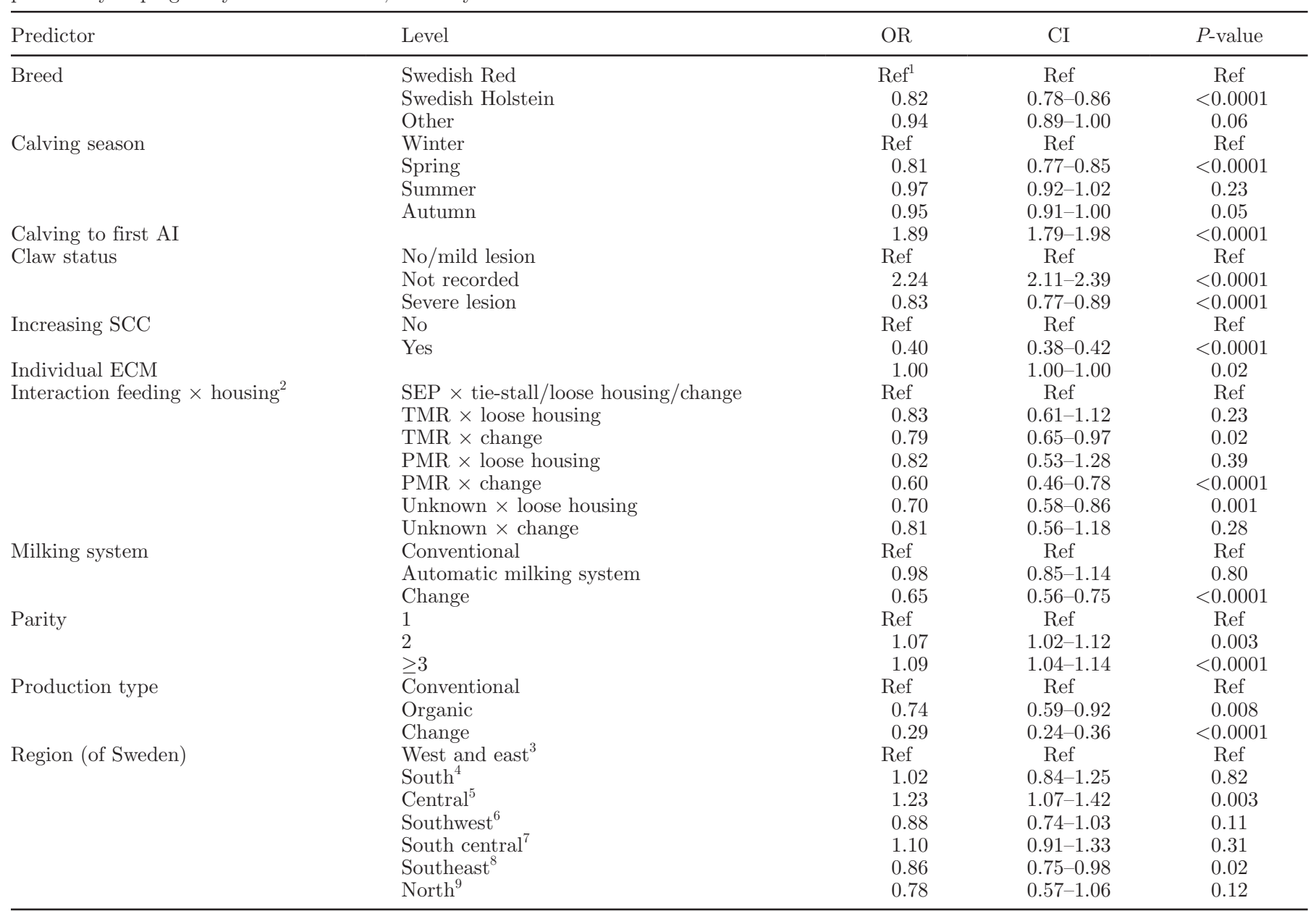

\footnotetext{
${ }^{1}$ Ref $=$ reference.

${ }^{2}$ Results for main effects are not shown. SEP = separate feeding; PMR = partial mixed ration.

${ }^{3}$ Corresponding to the former regional dairy association of Freja Husdjur.

${ }^{4}$ Corresponding to the present regional dairy association of Skåne Semin.

${ }^{5}$ Corresponding to the former regional dairy association of Svea Husdjur.

${ }^{6}$ Corresponding to the former regional dairy association of Hallands Husdjur.

${ }^{7}$ Corresponding to the present regional dairy association of Södra Älvsborgs Husdjur.

${ }^{8}$ Corresponding to the former regional dairy association of Hansa Husdjur.

${ }^{9}$ Corresponding to the former regional dairy association of Norrmejeriers producenttjänst.
}

\section{DISCUSSION}

This comprehensive study of 63,561 Swedish dairy cows showed that some of the risk factors related to the very rapid and ongoing change in the dairy industry are affecting cow fertility negatively. Cows that calved and were inseminated in herds changing housing, milking, or production system (e.g., changing from tie-stall to loose housing, from conventional milking to AMS, or from conventional to organic management) all had lower probability of PAI and received more inseminations when submitted to AI. The reproductive performance was not affected in cows having their reproduc- tive periods of interest before or after the change in housing or milking system. It is not surprising that a change in herd management system leads to a transient impairment of reproductive performance for several conceivable reasons. For example, a major change on the farm is likely to alter the normal routines in the herd, resulting in a lower heat detection rate and fewer cows inseminated in time. The general stress level in the herd may also be increased, which may affect the cows negatively. However, one may speculate that once routines (e.g., in regard to heat detection) have been adapted to the new system, the reproductive performance of the cows stabilizes. 
Table 3. Results [shown as incidence risk ratios (IR) and their 95\% CI] of a Poisson regression model used to investigate the effect of the number of inseminations in animals submitted for AI in 63,561 Swedish dairy cows

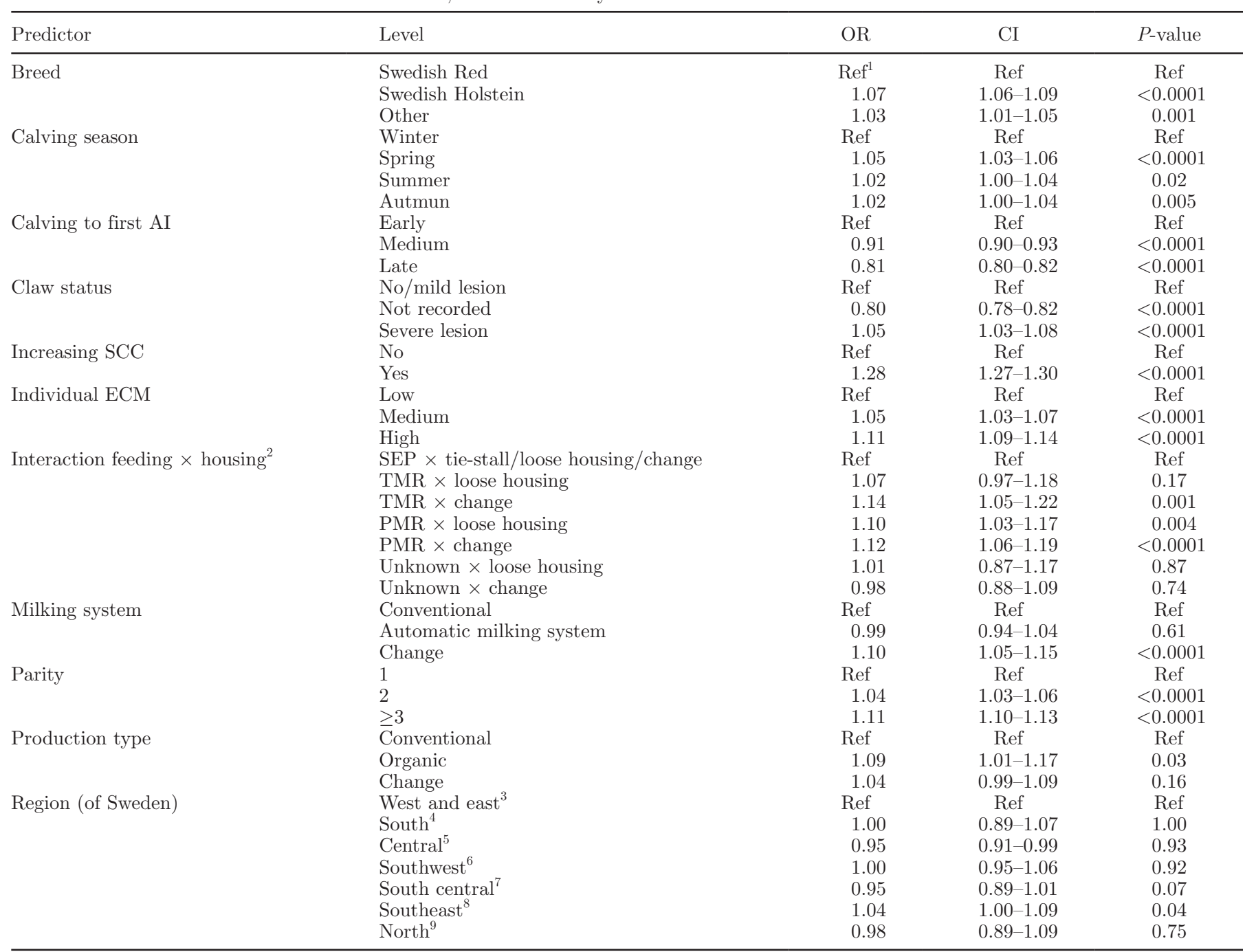

${ }^{1}$ Ref $=$ reference.

${ }^{2}$ Results for main effects are not shown. SEP $=$ separate feeding; $\mathrm{PMR}=$ partial mixed ration.

${ }^{3}$ Corresponding to the former regional dairy association of Freja Husdjur.

${ }^{4}$ Corresponding to the present regional dairy association of Skåne Semin.

${ }^{5}$ Corresponding to the former regional dairy association of Svea Husdjur.

${ }^{6}$ Corresponding to the former regional dairy association of Hallands Husdjur.

${ }^{7}$ Corresponding to the present regional dairy association of Södra Älvsborgs Husdjur.

${ }^{8}$ Corresponding to the former regional dairy association of Hansa Husdjur.

${ }^{9}$ Corresponding to the former regional dairy association of Norrmejeriers producenttjänst.

Cows fed TMR or PMR and kept in a loose-housing system did not have a lower probability of PAI than cows fed separately in tie-stalls. This finding can allay the concerns within the Swedish dairy sector that TMR and PMR may be possible risk factors for decreased fertility (Spörndly, 2005). Results supporting these concerns were previously reported by Löf et al. (2007), who found that herds with TMR feeding had longer calving intervals and calving to last AI intervals than herds that did not use TMR. However, a more recent risk factor study from the same group (Löf, 2012), which investigated the chance of a cow being pregnant $30 \mathrm{~d}$ after the herd's calculated voluntary waiting period, found that reproductive performance did not differ between TMR-fed and individually fed cows. This could indicate that farmers and feed advisors have become more skilled in managing the TMR or PMR fed herd over the years. 
According to the present study, cows milked in an AMS do not have different reproductive performance than cows milked in a conventional milking system. Our findings are in concordance with those reported by Löf (2012) and Kruip et al. (2002). Although the limited amount of time spent per cow may lead to less focus on reproductive management, the use of electronic activity tags, which are commonly included in AMS systems, can compensate for this (Løvendahl and Chagunda, 2010). However, all AMS systems are not equally designed and the type of traffic (forced or free) may influence the eating behavior of the cows (Bach et al., 2009). Among Swedish herds, guided or free traffic dominate. To our knowledge, no studies exist investigating the effect of guided traffic on fertility, but it cannot be ruled out that cow fertility is affected by traffic type.

Claw status and lameness of dairy cows have earlier been shown to be a risk factor for decreased fertility (Collick et al., 1989; Barkema et al., 1994; Hultgren et al., 2004). In the present study, we found that cows diagnosed with severe claw lesions had a lower probability of PAI and increased NINS. Other studies have found lame cows to be mounted less frequently and to express estrus of lower intensity (Walker et al., 2010). In addition, Morris et al. (2011) found that almost one-third of the lame cows failed to ovulate, had lower LH pulse frequency, and lower estradiol concentration. In the present study, heel horn erosion, dermatitis, and mild sole hemorrhages were categorized as mild claw lesions. Although lesions from digital dermatitis may cause lameness, these were not categorized as severe because the different types of dermatitis were not accurately distinguishable in the database. The estimates from the present study also showed that the absence of a claw health record (which is not similar to no trimming) was associated with higher reproductive performance. However, because claw recordings are made voluntarily (unlike, for example, monthly milk recordings, which are compulsory when the herd is affiliated with SOMRS), information may be insufficient to draw conclusions about this group and a direct causal relationship is, of course, not expected. We believe that herd health programs and research, and in the end, cow welfare, would benefit if reporting of claw-trimming events was made compulsory. It is clear that, because the structural changes in the dairy sector may lead to a higher incidence of claw diseases and lameness (Bergsten and Herlin, 1996; Kujala et al., 2009), it is important to include a structured approach to minimize claw diseases when planning herd health programs.

Cows that displayed increasing SCC after calving had a halved probability of PAI and it is possible that these cows could, at the time, have been actively developing either clinical or subclinical mastitis. Similarly, Lavon et al. (2011) and Hudson et al. (2012) found that an elevation in SCC around the time of AI reduced pregnancy rates. Cows with mastitis may have decreased LH pulsatility, absent LH surge, and reduced signs of estrus (Hockett et al., 2005). Also, herds with a high incidence of mastitis are reported to have a high level of metabolic stress (Holtenius et al., 2004) and, thus, a subsequent risk for decreased fertility (Friggens, 2003). In the present study, having a high SCC per se was not associated with cow fertility, whereas increasing SCC had a negative association, indicating that it was worse to become a case of high SCC than being a case of high SCC. However, the high SCC variable was defined to cover a relatively large period and it is possible that a different definition and more detailed data would detect a significant association. Ultimately, it is likely that management that supports udder health also leads to good reproductive performance.

In the regression analyses, many predictor variables were found to be statistically significant - a feature commonly observed when data includes many observations. An examination of the magnitude of the association (i.e., the OR), the range of the $95 \%$ confidence interval, and the interquartile range (of continuous variables) can be made to evaluate the biological significance of each finding (e.g., for the variables parity and milk yield in the PAI model, the estimates were generally small). Also in the NINS model, many significant predictor variables had a small magnitude of association with the outcome. The latter could be due to the fact that NINS to a larger extent is affected by decisions made by the farmer (rather than by biology alone). To be able to show their small magnitude of association, the variables were kept in the models.

In the present study, feed advice based on monthly measurements of BCS in all cows and milk yield was not associated with the reproductive performance of the cows. In contrast, findings by Löf et al. (2007) indicated that herds with advanced feed advisory services had shorter intervals from calving to first AI. In the present study, the compliance of the farmers to the advice given was not known, which might have influenced the results.

\section{CONCLUSIONS}

The ongoing trends in the dairy sector for larger herds, group feeding systems, and more automation will not necessarily lead to impaired reproductive performance. Our results indicate that major changes in management, rather than the new types of milking or housing system per se, negatively affects reproductive performance. More studies are required to determine 
the most critical post-change period in relation to reproductive events. However, preventing animal health disturbances (e.g., by regular and functional claw trimming and a structured approach to minimize increasing SCC after calving) is of great importance to manage reproductive performance successfully.

\section{ACKNOWLEDGMENTS}

H. Lomander was financially supported by the Swedish Farmers' Foundation for Agricultural Research (Stockholm, Sweden). The study was also partly supported by Skaraborgs län nötkreatursförsäkringsbolag (Skara, Sweden). The authors thank Ane Nødtvedt (Norwegian School of Veterinary Science, Oslo, Norway) for valuable input on the manuscript.

\section{REFERENCES}

Bach, A., M. Devant, C. Iglesias, and A. Ferrer. 2009. Forced traffic in automatic milking systems effectively reduces the need to get cows, but alters eating behavior and does not improve milk yield of dairy cattle. J. Dairy Sci. 92:1272-1280.

Barkema, H. W., J. D. Westrik, K. A. S. van Keulen, Y. H. Schukken, and A. Brand. 1994. The effects of lameness on reproductive performance, milk production and culling in Dutch dairy farms. Prev. Vet. Med. 20:249-259.

Bergsten, C., and A. H. Herlin. 1996. Sole haemorrhages and heel horn erosion in dairy cows: The influence of housing system on their prevalence and severity. Acta Vet. Scand. 37:395-408.

Collick, D. W., W. R. Ward, and H. Dobson. 1989. Associations between types of lameness and fertility. Vet. Rec. 125:103-106.

Eriksson, J.-Å. 2006. Swedish sire evaluation of hoof disease based on hoof trimming records. Interbull Bull. 35:49-52.

Friggens, N. C. 2003. Body lipid reserves and the reproductive cycle: Towards a better understanding. Livest. Prod. Sci. 83:219-236.

Hockett, M. E., R. A. Almeida, N. R. Rohrbach, S. P. Oliver, H. H. Dowlen, and F. N. Schrick. 2005. Effects of induced clinical mastitis during preovulation on endocrine and follicular function. J. Dairy Sci. 88:2422-2431.

Holtenius, K., K. Persson Waller, B. Essén-Gustavsson, P. Holtenius, and C. Hallén Sandgren. 2004. Metabolic parameters and blood leukocyte profiles in cows from herds with high or low mastitis incidence. Vet. J. 168:65-73.

Hosmer, D. V., and S. Lemeshow. 2000. Applied Logistic Regression. 2nd ed. John Wiley \& Sons Inc., New York, NY.

Hovinen, M., M. D. Rasmussen, and S. P. Pyörälä. 2009. Udder health of cows changing from tie stalls or free stalls with conventional milking to free stalls with either conventional or automatic milking. J. Dairy Sci. 92:3696-3703.

Hudson, C. D., A. J. Bradley, J. E. Breen, and M. J. Green. 2012. Associations between udder health and reproductive performance in United Kingdom dairy cows. J. Dairy Sci. 95:3683-3697.

Hultgren, J., T. Manske, and C. Bergsten. 2004. Associations of sole ulcer at claw trimming with reproductive performance, udder health, milk yield, and culling in Swedish dairy cattle. Prev. Vet. Med. 62:233-251.

Jacobs, J. A., and J. M. Siegford. 2012. Invited review: The impact of automatic milking systems on dairy cow management, behavior, health, and welfare. J. Dairy Sci. 95:2227-2247.

Koning, K. d., and J. Rodenburg. 2004. Automatic milking: State of the art in Europe and North America. Pages 27-37 in Automatic Milking: A Better Understanding. A. Meijering, H. Hogeveen, and C. J. A. M. de Koning, ed. Wageningen Academic Publishers, Wageningen, the Netherlands.
KRAV. 2013. KRAV standards. KRAV ekonomisk förening, Uppsala, Sweden. Accessed Jul. 31, 2013. http://www.krav.se/regel/kravsregler-2013.

Kruip, T. A. M., H. Morice, M. Robert, and W. Ouweltjes. 2002. Robotic milking and its effect on fertility and cell counts. J. Dairy Sci. 85:2576-2581.

Kujala, M., I. R. Dohoo, M. Laakso, C. Schnier, and T. Soveri. 2009. Sole ulcers in Finnish dairy cattle. Prev. Vet. Med. 89:227-236.

Lakic, B. 2011. Effects of a single prolonged milking interval in cows. Study of indicators and mediators of inflammation, milk composition and yield. PhD Thesis. Swedish University of Agricultural Sciences, Uppsala, Sweden. Acta Universitatis agriculturae Sueciae 2011:101. Accessed Jul. 31, 2013. http://pub.epsilon.slu. se/8478/1/lakic_b_111205.pdf.

Lavon, Y., E. Ezra, G. Leitner, and D. Wolfenson. 2011. Association of conception rate with pattern and level of somatic cell count elevation relative to time of insemination in dairy cows. J. Dairy Sci. 94:4538-4545.

Löf, E. 2012. Epidemiological studies of reproductive performance indicators in Swedish dairy cows. PhD Thesis. Swedish University of Agricultural Sciences, Uppsala, Sweden. Acta Universitatis agriculturae Sueciae 2012:28. Accessed Jul. 31, 2013. http://pub. epsilon.slu.se/8802/.

Löf, E., H. Gustafsson, and U. Emanuelson. 2007. Associations between herd characteristics and reproductive efficiency in dairy herds. J. Dairy Sci. 90:4897-4907.

Løvendahl, P., and M. G. G. Chagunda. 2010. On the use of physical activity monitoring for estrus detection in dairy cows. J. Dairy Sci. 93:249-259.

Lucy, M. C. 2001. Reproductive loss in high-producing dairy cattle: Where will it end? J. Dairy Sci. 84:1277-1293.

Morris, M. J., K. Kaneko, S. L. Walker, D. N. Jones, J. E. Routly, R. F. Smith, and H. Dobson. 2011. Influence of lameness on follicular growth, ovulation, reproductive hormone concentrations and estrus behavior in dairy cows. Theriogenology 76:658-668.

Nielsen, N. I., A. Hameleers, F. J. Young, T. Larsen, and N. C. Friggens. 2010. Energy intake in late gestation affects blood metabolites in early lactation independently of milk production in dairy cows. Animal 4:52-60.

Olsson, S.-O., P. Baekbo, S. Ö. Hansson, H. Rautala, and O. Østerås. 2001. Disease recording systems and herd health schemes for production diseases. Acta Vet. Scand. Suppl. 94:51-60.

Rodriguez-Martinez, H., J. Hultgren, R. Båge, A.-S. Bergqvist, C. Svensson, C. Bergsten, L. Lidfors, S. Gunnarsson, B. Algers, U. Emanuelson, B. Berglund, G. Andersson, M. Håård, B. Lindhé, H. Stålhammar, and H. Gustafsson. 2008. Reproductive performance in high-yielding dairy cows: Can we sustain it under current practice? doi: R0108.1208. Int. Vet. Info. Serv. Accessed Jul. 31, 2013. http://www.ivis.org/reviews/rev/rodriguez/chapter.asp?la=1.

Spörndly, R. 2005. Fullfoder/Blandfoder. Får vi det att fungera i praktiken? In Proceedings of Svensk mjölks djurhälso och utfodringskonferens 2005, Jönköping, Sweden. Swedish Dairy Association, Stockholm, Sweden.

Swedish Board of Agriculture. 2012. Yearbook of Agricultural Statistics 2012 including food statistics, Jönköping, Sweden. Accessed Jul. 31, 2013. http://www.jordbruksverket.se/omjordbruksverket/ statistik/jordbruksstatistiskarsbok/jordbruksstatistiskarsbok2012. 4.50fac94e137b680908480003982.html.

Swedish Dairy Association. 2012. Cattle Statistics. Swedish Dairy Association, Stockholm, Sweden.

von Elm, E., D. G. Altman, M. Egger, S. J. Pocock, P. C. Gøtzsche, and J. P. Vandenbroucke. 2007. The strengthening the reporting of observational studies in epidemiology (STROBE) statement: Guidelines for reporting observational studies. Lancet 370:14531457.

Walker, S. L., R. F. Smith, D. N. Jones, J. E. Routly, M. J. Morris, and H. Dobson. 2010. The effect of a chronic stressor, lameness, on detailed sexual behaviour and hormonal profiles in milk and plasma of dairy cattle. Reprod. Domest. Anim. 45:109-117. 